\title{
Social justice, human rights and mental illness
}

Brendan D Kelly

The Mental Health Act 2001 focuses chiefly on two aspects of mental health services in Ireland: involuntary detention of individuals with mental illness and mechanisms for assuring standards of care. ${ }^{1}$ In the complicated setting of mental health care, it is clearly essential that involuntary detention is appropriately regulated and monitored, so as to preserve the individual's right to liberty. An exclusive focus on this right alone, however, fails to address or even acknowledge a range of broader social injustices and denials of human rights commonly experienced by individuals with enduring mental illness.

In the first instance, individuals with enduring mental illness have increased rates of homelessness in almost all countries studied. ${ }^{2-4}$ They also tend to experience obstacles accessing community care services following discharge from hospital ${ }^{5}$ and have particular difficulties with re-integration into society. ${ }^{6}$ These problems are compounded by fact that lower socio-economic group is associated not only with increased rates of mental illness ${ }^{7.9}$ but also with younger age at presentation $^{10}$ and longer durations of untreated illness ${ }^{11}$ - clinical features which are strongly associated with more severe forms of illness ${ }^{12}$ and poorer outcomes. ${ }^{13}$

Secondly, there is a high prevalence of enduring mental illness in prison populations: in Ireland, the six-month prevalence of psychosis in life-sentenced male prisoners is $7.1 \%{ }^{14}$ One systematic review of 62 studies from 12 countries found that $10 \%$ of male and $12 \%$ of female prisoners had major depression, while $3.7 \%$ of male and $4 \%$ of female prisoners had psychoses, such as schizophrenia. ${ }^{15}$ These findings may be related to the facts that a person with mental iliness is more likely than a person without mental illness to be (a) arrested in similar circumstances: $;^{16}$ and (b) remanded in custody for a lesser offence. ${ }^{17}$

Thirdly, there are increased rates of certain mental illnesses, including schizophrenia and post-traumatic stress disorder, amongst migrant groups compared to native populations. ${ }^{18.21}$ This increased rate of enduring mental illness adds to the myriad other stressors experienced by migrants, including human rights abuses in their countries of origin and enforced dispersal in their host countries. ${ }^{21-23}$

These associations between mental illness and homelessness, socio-economic deprivation, imprisonment and the negative social concomitants of migration can be seen as a

Brendan D Kelly, MD, MA, MSc, MRCPI, MRCPsych, Senior Lecturer in Psychiatry, Department of Adult Psychiatry, University College Dublin, Mater Misericordiae University Hospital, 62/63 Eccles Street, Dublin 7, Ireland.

SUBMITTED: JANUARY 10, 2007. ACCEPTED: FEBRUARY 5, 2007 form of societal or 'structural' violence ${ }^{24}$ that results in the systematic exclusion of individuals with mental illness from full participation in civic, social and political life..$^{25}$ These associations also demonstrate that human rights issues for individuals with mental illness extend well beyond the issue of involuntary detention: these social injustices and denials of human rights are attributable to much broader societal factors that are likely to include general levels of public service provision (especially mental health service resourcing), the design of public service delivery mechanisms, and general societal attitudes towards individuals with mental illness.

Potential solutions to these problems are likely to be complex and to centre on the enhancement of individual agency amongst the mentally ill and their families. ${ }^{26}$ Specific measures may include:

- Enhancing advocacy, empowerment and guardianship processes $^{27}$

- Deepening governance, accountability and quality procedures in mental health services ${ }^{28,29}$ and other public services (eg. housing programmes)

- Enhancing direct political participation (eg. voter-registration programmes) and enhancing the roles and effectiveness of interest groups and service-user organisations $^{26}$

- Adapting the concept of 'soft power' to strengthen advocacy programmes and public education initiatives. ${ }^{26,27,30}$

Initiatives related to information technology and electronic democracy may have a particular role to play in enhancing democratic participation in this group. ${ }^{31}$ Individuals with mental illness may, however, experience difficulty accessing e-technology owing to socio-economic deprivation ${ }^{7 \cdot 9}$ and homelessness ${ }^{2-4}$ both of which reduce access to e-technology. ${ }^{32}$ Other obstacles may include gender, ${ }^{33}$ impaired literacy ${ }^{34,35}$ and cognitive impairments, ${ }^{36-38}$ including specific deficits in reading and reading comprehension. ${ }^{38}$

Nonetheless, if some these factors are addressed in a pragmatic and equitable fashion, there may be an important role for e-technology in creating a public space in which issues related to empowerment and stigma ${ }^{40,41}$ can be discussed and addressed. This is one of the areas in which e-technology, with its varying levels of anonymity and disclosure, may prove particularly empowering for individuals with mental illness, as well as informative for people who know little about this area.

In Victoria, Australia, the Prahran Mission Public Internet Access programme is one example of a project aimed specifically at providing Internet access for individuals with mental illness in settings in which they are likely to feel comfortable, supported and able to express their needs and interests clearly. ${ }^{42}$ If problems related to the 'digital divide' can be over- 
come, access to this level of information technology can have substantial empowering and enabling effects amongst individuals who may be otherwise disempowered, marginalised or socially excluded..$^{43}$

These are just some of the measures that may prove useful in addressing the effects of 'structural violence ${ }^{25}$ and reducing the societal 'power deficit' routinely experienced by individuals with enduring mental illness..$^{26}$ It is essential that such measures acknowledge the broader, societal basis for much of the social exclusion, systematic discrimination and abuse of human rights experienced by individuals with enduring mental illness. Protecting the right to freedom is certainly an essential starting point, but it is the observance or denial of other rights that determines precisely what that freedom means.

Declaration of Interest: The author is trainee editor of the Irish Journal of Psychological Medicine. There is no other interest to declare.

\section{References}

1. Kelly BD. The Irish Mental Health Act 2001. Psychiatric Bull 2007; 31: 21-24.

2. George SL, Shanks NJ, Westlake L. Census of Single Homeless People in Sheffield. BMJ 1991; 302: 1387-1389.

3. Holohan TW, Holohan W. Health and Homelessness in Dublin. Ir Med J 2000; 93 : 41-43.

4. Teesson M, Hodder T, Buhrich N. Psychiatric disorders in homeless men and women in inner Sydney. Aust New Zealand J Psychiatry 2004; 38: 162-168.

5. Melzer D, Hale AS, Malik SJ, Hogman GA, Wood S. Community care for patients with schizophrenia one year after hospital discharge. BMJ 1991; 303: 1023-1026.

6. Yanos PT, Barrow SM, Tsemberis S. Community integration in the early phase of housing among homeless persons diagnosed with severe mental illiness. Comm Mental Health J 2004; 40: 133.150.

7. Faris RB, Dunham HW. Mental disorders in urban areas. Chicago: University of Chicago Press, 1939

8. Croudace TJ, Kayne R, Jones PB, Harrison GL. Non-linear relationship between an index of social deprivation, psychiatric admission prevalence and the incidence of psychosis. Psychological Med 2000; 30: 177-185.

9. Eaton WW. The sociology of mental disorders. New York: Praeger, 1980.

10. Mulvany F, O'Callaghan $E$, Takei N, Byrne M, Fearon P, Larkin C. Effect of socia class at birth on risk and presentation of schizophrenia. BMJ 2001; 323: 1398-1401 11. Clarke $\mathrm{M}$ et al. Duration of untreated psychosis in first episode schizophrenia and its reiationship to premorbid functioning. Schizophrenia Research 1999; 36s: 38-39.

12. Bellino $S$ et al. Relationships of age at onset with clinical features and cognitive functions in a sample of schizophrenia patients. J Clin Psychiatry 2004; 65: 908-914. 13. Addington J, Van Mastrigt S, Addington D. Duration of untreated psychosis. Psychological Med 2004; 34: 277-284.

14. Duffy D, Linehan S, Kennedy HG. Psychiatric morbidity in the male sentenced Irish prisons population. ir J Psychological Med 2006; 23: 54-62.

15. Fazel S, Danesh J. Serious mental disorder in 23,000 prisoners: a systematic review of 62 surveys. Lancet 2002; 359: 545-550

16. Teplin LA. Criminalizing mental disorder. The comparative arrest rate of the mentally ill. Am Psychologist 1984; 39: 794-803.

17. Tayłor PJ, Gunn J. Violence and psychosis. I. Risk of violence among psychotic men BMJ (Clinical Research Edition) 1984; 288: 1945-1949.

18. Lavik NJ, Edvard H, Oivind S, Anders S. Mental disorder among refugees and the impact of persecution and exile. Brit J Psychiatry 1996; 169: 726-732.

19. Selten JP, Slaets JP, Kahn RS. Schizophrenia in Surinamese and Dutch Antillean immigrants to The Netherlands. Psychological Med 1997; 27: 807-811.

20. Harrison G. Searching for the causes of schizophrenia: the role of migrant studies. Schizophrenia Bull 1990; 16: 663-671.

21. Kelly BD. Globalization and psychiatry. Advances in Psychiatric Treatment 2003; 9: 464-474.

22. Silove D, Steel Z, Watters C. Policies of deterrence and the mental health of asylum seekers. JAMA 2000; 284: 604-611.

23. Gavin BE, Kelly BD, Lane A, O'Callaghan E. The mental health of migrants. Ir Med J 2001; 94: 229-230.

24. Farmer P. Pathologies of power. Berkeley: University of California Press, 2003.

25. Kelly BD. Structural violence and schizophrenia. Soc Sci and Med 2005; 61: 721 . 730 .

26. Kelly BD. The power gap: Freedom, power and mental illness. Soc Sci and Med 2006; 63: 2118-2128.

27. Edd JR, Fox PG, Burns K. Advocating for the rights of the mentally ill: A global issue. Int J Psychiatric Nursing Res 2005; 11: 1211-1217.

28. Palmer C. Clinical governance: breathing new life into clinical audit. Adv in Psychiatric Treat 2002; 8: 470-476.

29. James A, Kendall T, Worrall A. Clinical Governance in Mental Health and Learning Disability Services: A Practical Guide. London: Gaskell, 2005.

30. Nye JS. Soft power: the means to success in world politics. New York: Public Affairs, 2004.

31. Morison J, Newman DR. On-line citizenship: consultation and participation in New Labour's Britain and beyond. Int Rev Law Computers and Tech 2001; 15: 171-194.

32. Eurostat. The Digital Divide in Europe. Statistics in Focus 2005; 38: 1.

33. Working Group on Women, Mental Health, Mental lilness and Addictions. Women, mental health and mental illness and addiction in Canada: An overview. Canada: Canadian Women's Health Network and Centres for Excellence for Women's Health, 2006.

34. Christensen RC, Grace GD. The prevalence of low literacy in an indigent psychiatric population. Psychiatric Services 1999; 50: 262-263.

35. Sentell TL, Shumway MA. Low literacy and mental illness in a nationally representative sample. J Nerv Mental Dis 2003; 191: 549-552.

36. Jones $\mathrm{P}$, Rodgers $\mathrm{B}$, Murray R, Marmot M. Child development risk factors for adult schizophrenia in the British 1946 birth cohort. Lancet 1994; 344: 1398-1402.

37. Browne S, Clarke M, Gervin M, Lane A, Waddington JL, Larkin C, O'Callaghan E. Determinants of neurological dysfunction in first episode schizophrenia. Psychological Med 2000; 30: 1433-1441.

38. Rosso IM et al. Childhood neuromotor dysfunction in schizophrenia patients and their unaffected siblings: a prospective cohort study. Schizophrenia Bull 2000; 26: 367378.

39. Reichenberg $A$ et al. A population-based cohort study of premorbid intellectual, language and behavioural functioning in patients with schizophrenia, schizoaffective disorder and nonpsychotic bipolar disorder. Am J Psychiatry 2002; 159: 2027-2035. 40. Goffman E. Stigma: notes on the management of spoiled identity. Englewood Cliffs (NJ): Prentice-Hall, 1963.

41. Byrne P. Stigma of mental illness and ways of diminishing it. Adv Psychiatric Treat 2000; 6: 65-72.

42. Minister for Information and Communication Technology. Brack's government boosts Internet access for disadvantaged in Stonnington, Victoria, Australia, Ministry for Information and Communication Technology, 2006.

43. Economist. Globalisation: Making Sense of an Integrating World. London, Economist/Profile, 2001. 
When patients

with depression

reach remission on

Cymbalta 60mg ${ }^{*}$.

\section{it shows!}

- determining remission from depression, patients consider a return to one's usual, normal self as very important.

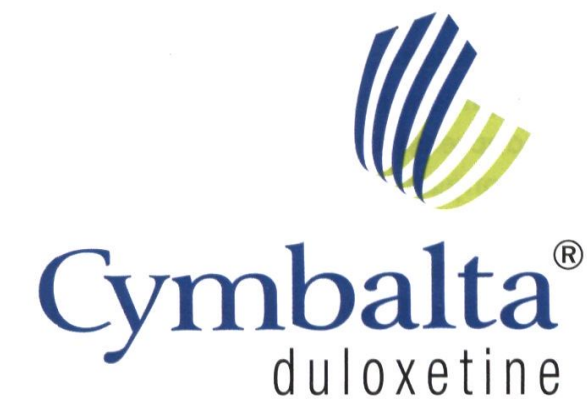

CYMBALTA* (DULOXETINE) REPUBLIC OF IRELAND ABBREVIATED PRESCRIBING INFORMATION the elderly. Caution is required in patients at increased risk for hyponatraemia, such as elderly, cirrhotic, or
Presentation Hard gastro-resistant capsules, 30mg or 60mg of duloxetine. Also contains sucrose. Uses dehydrated patients, or patients treated with diuretics. Hyponatraemia may be due to a syndrome

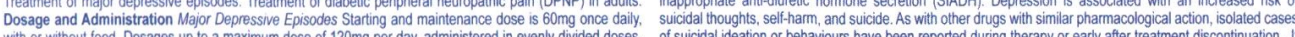

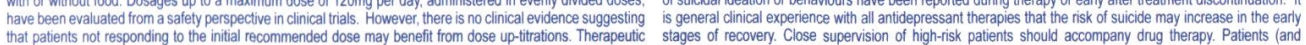

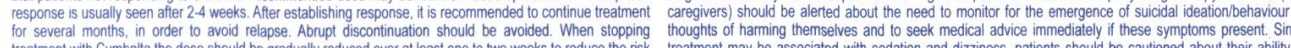

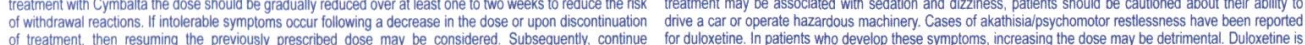

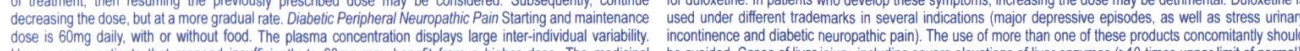

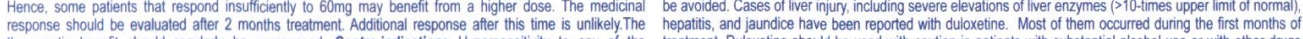

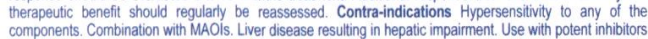

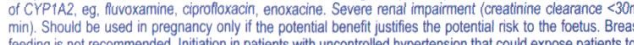

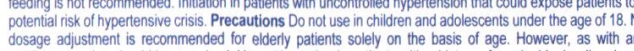

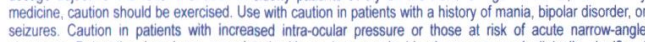

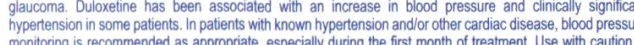

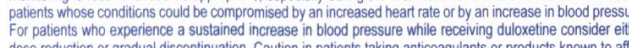

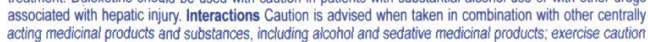

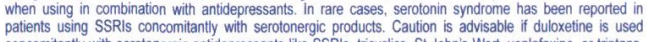

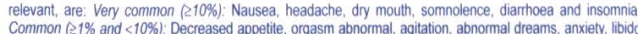

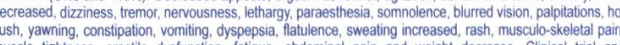

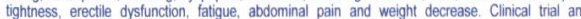

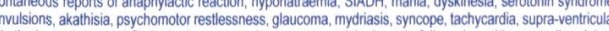

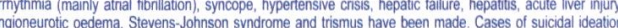

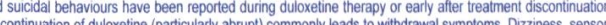

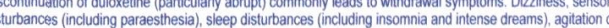

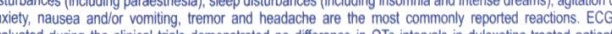

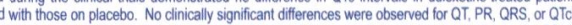

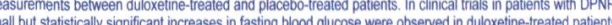

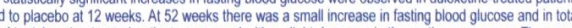

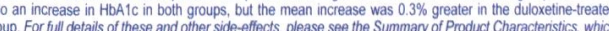

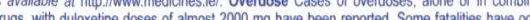

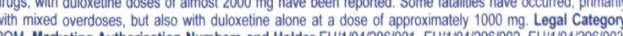

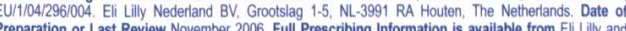

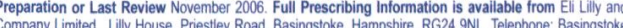

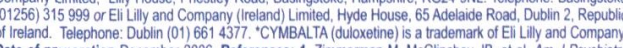

